\title{
Caulerpa prolifera stable isotope ratios reveal anthropogenic nutrients within a tidal lagoon
}

\author{
Edward P. Morris ${ }^{1, *}$, Gloria Peralta ${ }^{1}$, Javier Benavente ${ }^{2}$, Rosa Freitas ${ }^{4}$, \\ Ana Maria Rodrigues ${ }^{4}$, Victor Quintino ${ }^{4}$, Oscar Alvarez ${ }^{3}$, Nerea Valcárcel-Pérez ${ }^{1}$, \\ Juan José Vergara ${ }^{1}$, Ignacio Hernández ${ }^{1}$, J. Lucas Pérez-Lloréns ${ }^{1}$
}

${ }^{1}$ Department of Biology, and ${ }^{2}$ Department of Geology, and ${ }^{3}$ Department of Physical Oceanography, Faculty of Marine and Environmental Sciences, University of Cádiz, 11510 Puerto Real (Cádiz), Spain

${ }^{4}$ CESAM \& Department of Biology, University of Aveiro, 3810-193 Aveiro, Portugal

\begin{abstract}
Mapping of the nutrient content and isotopic composition of the native, rooted, green macroalga Caulerpa prolifera and the seagrass Cymodocea nodosa was conducted in the summer of 2006 within the inner Bay of Cádiz , SW Spain. Isotope values of suspended solids from aquaculture $\left(\delta^{15} \mathrm{~N}=9 \pm 0.88\right)$ and urban effluent $\left(\delta^{15} \mathrm{~N}=7 \pm 1.97\right)$ were similar to the isotopic composition of the macrophytes $\left(\delta^{15} \mathrm{~N}\right.$ range 3.4 to 8.1), suggesting the influence of anthropogenic nutrient sources throughout much of the bay. The $\mathrm{N}$ content of tissues (C. prolifera 3.0 to $4.9 \%$; C. nodosa 1.8 to $3.0 \%$ ) was highly associated with their isotopic composition, indicating that nutrient supply strongly influenced plant stoichiometry. Distance from the source, i.e. variation in water column nutrient concentration, which was also highly correlated with median current velocities $\left(0.03\right.$ to $\left.0.18 \mathrm{~m} \mathrm{~s}^{-1}\right)$ and to a lesser extent benthic light dose (1.8 to 10.7 mol quanta $\left.\mathrm{m}^{-2} \mathrm{~d}^{-1}\right)$, appeared to determine the mass transfer of $\mathrm{N}$ to the benthos. Significantly lower values of $C$. nodosa $\mathrm{N}$ content and $\delta^{15} \mathrm{~N}$ hint at the role strong gradients in environmental conditions may play in promoting the stable coexistence of seagrasses and C. prolifera within the bay. C. prolifera was a useful indicator species that, via the analysis of its tissue composition, can provide a highly effective tool to aid in the management of nutrient inputs within shallow, coastal zones.
\end{abstract}

KEY WORDS: Macroalgae $\cdot$ Nitrogen $\cdot \delta^{15} \mathrm{~N} \cdot \delta^{13} \mathrm{C} \cdot \mathrm{C}: \mathrm{N}$ ratio $\cdot$ Hydrodynamics $\cdot$ Seagrass $\cdot$ Bay of Cádiz

Resale or republication not permitted without written consent of the publisher

\section{INTRODUCTION}

Escalating urbanisation of the coastal zone combined with rapid population expansion (Small \& Nicholls 2003) have resulted in greater than ever anthropogenic nutrient inputs to coastal waters (Jickells 1998, Smith et al. 2006, Schlesinger 2009), particularly within the Mediterranean region (European Environment Agency 2006). Nutrient enrichment can lead to enhanced primary production by phytoplankton and opportunistic macroalgae and even direct toxic effects (Brun et al. 2002), eventually causing shifts in the benthic autotrophic community (Short et al. 1995, Herbert 1999). These shifts can have consequences for the diversity and functioning of coastal ecosystems (Bachelet et al. 2000, Worm et al. 2006, Corzo et al. 2009) and, disquietingly, may be rather difficult to reverse (Scheffer et al. 2001, Sundback et al. 2003, Herbert \& Fourqurean 2008).

Sources of anthropogenic nutrients to coastal waters are diverse, including atmospheric deposition, agricultural run-off, industrial and urban effluents, and aquaculture (Van Der Voet et al. 1996, Smith et al. 2006). Whilst diffuse sources may be more difficult to control, point sources, such as industrial, urban and aquaculture effluents can be identified, regulated and redistributed so as to reduce their local impact (Sales et al. 1983, Costanzo et al. 2005).

Nutrients derived from anthropogenic point sources often (but not always) have a distinctive isotopic com- 
position, allowing the extent of their influence to be inferred by examining the spatial distribution of stable isotopes within benthic macrophyte communities (Costanzo et al. 2001, 2005, Vizzini \& Mazzola 2004). Being generally sessile, the isotopic composition of macrophyte tissues represents the 'integrated' isotopic composition of the nutrient sources reaching the benthos within a certain time period, i.e. the turnover time of tissue regeneration (Fry 2006). Furthermore, under steady growth conditions, the $\mathrm{N}$ content (\% dry matter, DM) of macrophyte tissues often represents the specific $\mathrm{N}$ assimilation rate of the plants $\left(\mathrm{g} \mathrm{N} \mathrm{g}^{-1} \mathrm{DM} \mathrm{d}^{-1}\right)$ (Costanzo et al. 2000, Malta et al. 2005). Thus, when combined, the isotopic and nutrient composition of macrophyte tissues can potentially provide information on the source and magnitude of nutrient inputs to the benthos over time scales of days to months (Inglett \& Reddy 2006).

Nevertheless, care is required when interpreting variations in the isotopic composition of macrophytes (Fry 2006, Inglett \& Reddy 2006). Higher $\delta^{15} \mathrm{~N}$ values may be caused by sediment denitrification processes (Lund et al. 1999), whereas lower $\delta^{15} \mathrm{~N}$ values may represent microbial $\mathrm{N}$ fixation (France et al. 1998). Both trends have been reported in macrophyte-dominated sediments (Iizumi \& Yamamuro 2000, Welsh et al. 2000, Chisholm \& Moulin 2003). Furthermore, although fractionation during $\mathrm{N}$ assimilation appears to be low (<4\%) (Williams 1984, Brabandere et al. 2007), plants with different assimilation affinities for $\mathrm{N}$ species $\left(\mathrm{NH}_{4}{ }^{+}, \mathrm{NO}_{3}{ }^{-}\right.$, or DON [dissolved organic nitrogen]) (Cohen \& Fong 2004) or different proportions of sediment pore water $\mathrm{N}$ uptake, related to changes in plant morphology (Collado-Vides 2002, Malta et al. 2005), may also have different $\delta^{15} \mathrm{~N}$ values, often making intraspecific comparisons difficult.

Intraspecific differences in $\delta^{13} \mathrm{C}$ values are rather common (Raven et al. 2002), usually representing an organism's specific photosynthetic pathway and rate of photosynthesis (Raven et al. 1995, Grice et al. 1996). Assimilated $\mathrm{C}$ is known to undergo large and variable degrees of isotopic fractionation (Benedict et al. 1980) related to: (1) transport across the diffusive boundary layer and cell wall and (2) fixation by enzymes, such as Rubisco (Raven et al. 2002). Changes in the C source, possibly related to increasing reliance on dissolved bicarbonate $\left(\delta^{13} \mathrm{C} \approx 0\right)$, rather than dissolved $\mathrm{CO}_{2}$ (ca. -8) (Raven et al. 2002) or $\mathrm{C}$ derived from heterotrophic microbial activity (Staal et al. 2007), may also exuberate photosynthetic fractionation effects. Nevertheless, when the isotopic composition of 'man-made' nutrient sources is sufficiently distinct compared to environmental fractionation effects, $\delta^{13} \mathrm{C}$ values can also be used to map the transport of anthropogenic nutrients in a similar fashion to N (Le point et al. 2004).
Simultaneous examination of environmental conditions and plant stoichiometry can help with the interpretation of natural variations in macrophyte stable isotope values, allowing potential isotopic fractionation effects to be contrasted against the influence of anthropogenic nutrient sources. C:N ratios of aquatic plants are essentially controlled by the balance between 2 processes: mass transport of nutrients and absorption of light (Duarte 1992, Baird \& Middleton 2004). When, nutrient uptake is not kinetically limited, i.e. limited by the number of uptake sites and enzyme activity, such as often observed for $\mathrm{NH}_{4}{ }^{+}$(Thomas et al. 2000, Morris et al. 2008), mass transport is dependent on the concentration of the nutrient in the water column and factors that affect the vertical mass-transfer coefficient. These include water velocity $(u)$, roughness of the bottom, diffusivity of the nutrient and fluid viscosity (Thomas et al. 2000, Nishihara \& Ackerman 2007). Thus, increases in water column nutrient concentration or water velocity both lead to a strong, non-linear increase in the foliar $\mathrm{N}$ uptake of macrophyte communities (Hurd et al. 1996, Cornelisen \& Thomas 2006), which, under steady growth conditions, results in an increase in the $\mathrm{N}$ content of tissues (Costanzo et al. 2000, Malta et al. 2005, Cornelisen et al. 2007).

$\mathrm{C}$ assimilation appears to reach kinetic limitation at a relatively low water velocity $\left(<0.05 \mathrm{~m} \mathrm{~s}^{-1}\right.$; Koch 1994 , Enriquez \& Rodriguez-Roman 2006), possibly related to the presence of active carbon-concentrating mechanisms (CCMs) in many macrophytes (Beer \& Waisel 1979). However, photosynthesis is strongly influenced by the amount of light absorbed by the plants, which depends on water depth and, in tidal areas, is often controlled by the local hydrodynamic regime (via resuspension and tidal movements), as well as the intrinsic properties of the macrophyte canopy community, i.e. pigments, density and form of photosynthetic structures (Enríquez \& Pantoja-Reyes 2005).

The aim of the present study was to use the tissue composition of benthic macrophytes as an indicator of the sources and extent of anthropogenic nutrient inputs within the inner Bay of Cádiz, SW Spain (Fig. 1) - an area of 'Special Community Importance' (SCI), protected by both national and international legislation because of its significance for migrating bird species and wealth of biodiversity. The $\mathrm{N}$ and $\mathrm{C}$ isotopic composition of suspended solids collected from anthropogenic point sources of nutrients (urban and aquaculture effluent) were compared to the isotopic values of Caulerpa prolifera, a native rooted macroalgae, and the seagrass Cymodocea nodosa. Dominant environmental gradients (depth, median current velocity and light availability) were also characterised using a modelling approach (Alvarez et al. 1997) and the data from a recent $50 \mathrm{kHz}$ acoustic sounder (QTC-V) 


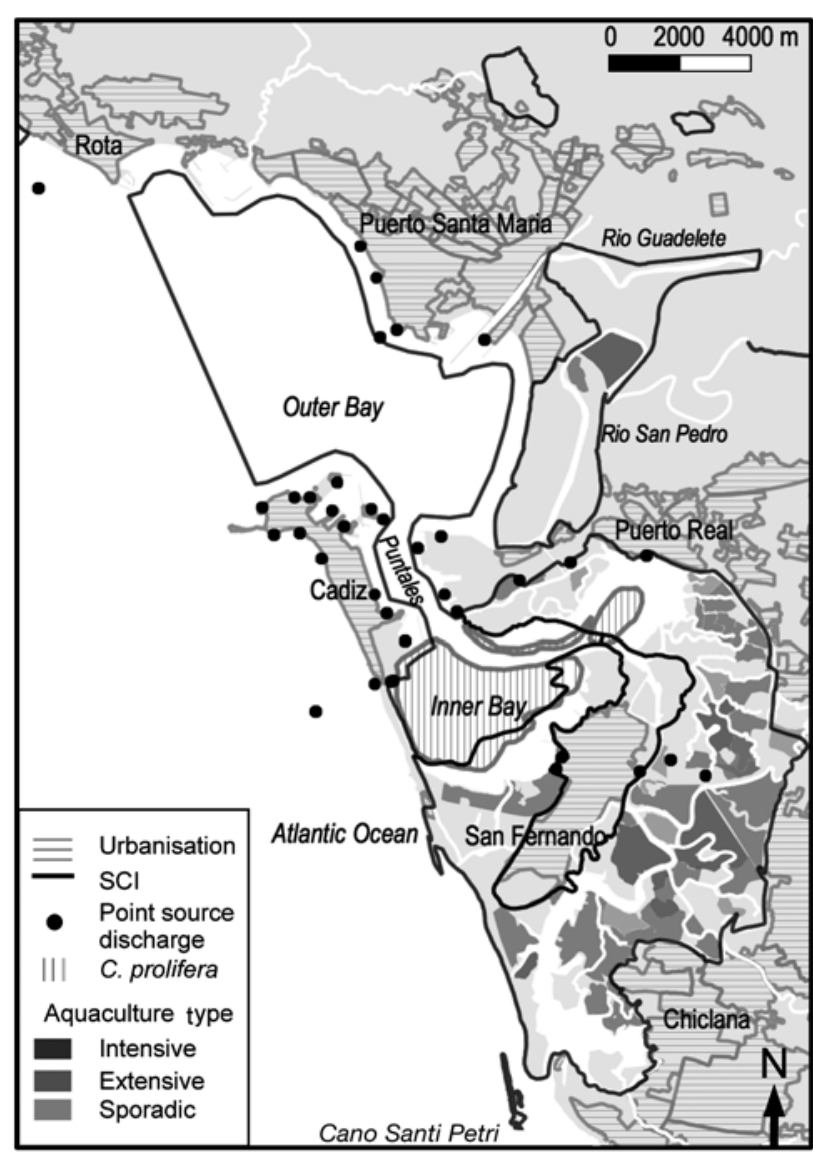

Fig. 1. Bay of Cádiz, SW Spain. Map showing centres of urbanisation, the distribution of the benthic macrophyte Caulerpa prolifera, aquaculture activities, point source discharges and areas of special community importance (SCI, ES0000140 \& ES6120009 EU Habitats Directive 92/43/CEE). Data provided by the 'Consejería de Agricultura y Pesca' and 'Consejería de Medio Ambiente' of the 'Junta de Andalucia'

survey (Freitas et al. 2008). These were compared to the spatial distribution of macrophyte tissue composition, providing insights into how environmental factors interact to influence nutrient transport and the ecophysiological impact of anthropogenic point sources on the benthic phototrophic community.

\section{MATERIALS AND METHODS}

Study area. Bay of Cádiz is located in the west of the Gulf of Cádiz, SW Spain, between $36^{\circ} 23^{\prime}$ to $36^{\circ} 37^{\prime} \mathrm{N}$ and $6^{\circ} 8^{\prime}$ to $6^{\circ} 15^{\prime} \mathrm{W}$ (Fig. 1). The bay is divided into 2 basins, a shallower inner bay with a mean depth of $3 \mathrm{~m}$ mean low water (MLW), and a deeper outer bay with a mean depth of $12 \mathrm{~m}$ MLW (Rueda \& Salas 2003). Sediment within the inner bay is composed mainly of fine sand and mud, with a high organic carbon content (Carrasco et al. 2003, Rueda \& Salas 2003). The inner bay is protected from the action of large waves, but is strongly influenced by semidiurnal co-oscillating tides with a mean amplitude of $1.5 \mathrm{~m}$ (Alvarez et al. 1997). The main water inputs into the inner bay are the tidal exchange with the outer bay (via the narrow 'Puntales' channel) and a number of smaller creeks and channels that connect to the surrounding salt marshes (Fig. 1). Tidal exchange is relatively high, with average water turnover rates ranging from 50 to $75 \%$ per tidal cycle (Alvarez et al. 1997).

The inner bay is a habitat of particular importance for local biodiversity (López de La Rosa et al. 2006). Intertidal areas support large populations of migrating birds (Perez-Hurtado et al. 1997). Extensive beds of rooted macrophytes cover almost the entire benthos. Caulerpa prolifera (Forsskål) J. V. Lamouroux, a native, rooted macroalgae, is numerically dominant and found throughout the subtidal regions. Three species of seagrass also inhabit the bay: Cymodocea nodosa Ucria (Ascherson) and Zostera marina L. occur in patches distributed throughout the shallow subtidal/intertidal regions, while Zostera noltii Hornem. is restricted to intertidal areas. These habitats, in turn, provide shelter and a structure for the settlement and growth of a large community of organisms (Drake \& Arias 1995, López de La Rosa et al. 2006), including a number of commercially important species (Rueda \& Salas 2003). In recognition of these valuable natural resources, parts of the bay have been declared Specially Protected Areas (SPA) and areas of 'Special Community Importance' (SCI) under European legislation (Birds Directive 79/409/CEE, ES0000140 2006/ $613 / \mathrm{CE})$, most of the intertidal areas are a Natural Park (Law 2/1989/CA) and RAMSAR site (1265, 24/10/02), and the subtidal areas are SCI integrated within the Nature 2000 Network (ES6120009, EU Habitats Directive 92/43/CEE, 2006/613/CE).

Anthropogenic point nutrient sources. The surrounding region is highly urbanised (Fig. 1), with a resident population of about 600000 people that almost doubles in summer due to an influx of tourists. Even though a number of waster water facilities still discharge into the outer bay, successful legislation, regulation and redirection of effluents have led to a greatly improved situation compared to that in the 1980s (Sales et al. 1983, Carrasco et al. 2003). On the other hand, as the environmental quality of the bay has improved, the aquaculture of commercially important species has been increasingly promoted within the surrounding salt marshes (Manzano Harriero et al. 2002, Macías et al. 2005), resulting in substantial nutrient inputs within certain regions (Tovar et al. 2000b, de la Paz et al. 2008, Ferrón et al. 2009).

The total area dedicated to aquaculture in 2001 was $29 \mathrm{~km}^{2}$ (Fig. 1). Although, generally extensive (area: 
$18.5 \mathrm{~km}^{2}$ ), a number of intensive/semi-intensive fishrearing operations were situated throughout the bay $\left(7.0 \mathrm{~km}^{2}\right)$, with the remaining $3.5 \mathrm{~km}^{2}$ dedicated to sporadic/irregular aquaculture activities (Manzano Harriero et al. 2002). Estimates of total nitrogen (Tot-N, kg $\mathrm{d}^{-1}$ ), suspended solids (TSS, $\mathrm{kg} \mathrm{d}^{-1}$ ) and phosphorous (Tot-P $\mathrm{kg} \mathrm{d}^{-1}$ ) discharges from a $1.3 \mathrm{~km}^{2}$ intensive

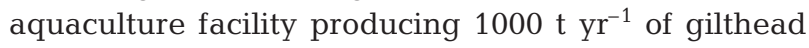
bream Sparus aurata within the Rio San Pedro were calculated by Tovar et al. (2000a). Using these estimates and assuming extensive and sporadic aquaculture discharges are $10 \%$ of the intensive culture, aquaculture activities were calculated to produce about $469527 \mathrm{~kg} \mathrm{TSS} \mathrm{d}^{-1}, 2491 \mathrm{~kg}$ Tot- $\mathrm{N} \mathrm{d}^{-1}$ and $134 \mathrm{~kg}$ Tot$\mathrm{P} \mathrm{d}^{-1}$ (Fig. 2; only discharges from intensive aquaculture are shown). Note the rather high TSS discharges are most likely related to resuspended sediment from the clay ponds, rather than organic matter.

Estimates of daily Tot-N, TSS and Tot-P discharged from large urban wastewater outfalls during 2006 (Fig. 2; only discharges from large sources are shown) were calculated by converting person equivalent units (p.e., the organic biodegradable load with a $5 \mathrm{~d}$ biochemical oxygen demand $\left[\mathrm{BOD}_{5}\right.$ ] of $60 \mathrm{~g} \mathrm{O}_{2} \mathrm{~d}^{-1}$ ) into matter loadings entering the wastewater facilities and adjusting for the type of treatment received (Tchobanoglous et al. 2003). Wastewater discharges in 2006 were estimated to be $12044 \mathrm{~kg} \mathrm{TSS} \mathrm{d}{ }^{-1}, 9400 \mathrm{~kg}$ Tot-N $\mathrm{d}^{-1}$ and $1864 \mathrm{~kg}$ Tot-P d $\mathrm{d}^{-1}$. No attempt was made to estimate nutrient discharges from the smaller industrial, urban and pluvial point sources.

Water column nutrients. Annual mean water column dissolved inorganic $\mathrm{N}$ concentrations published by the Andalusian department for environment in 2004 (Fig. 2A), ranged from a maximum of $14 \mu \mathrm{mol} \mathrm{N}^{-1}$ within the bay to a minimum of $2 \mu \mathrm{mol} \mathrm{N} \mathrm{l^{-1 }}$ along the Atlantic coast. Concentrations of $\mathrm{NH}_{4}{ }^{+}, \mathrm{NO}_{3}{ }^{-}, \mathrm{PO}_{4}{ }^{3-}$ and $\mathrm{SiO}_{4}{ }^{4-}$ measured during a number of tidal cycles in the Puntales channel the month before sampling was conducted were $5.6 \pm 4.3,1.3 \pm 1.4,1.5 \pm 1.8$, and $4.5 \pm 3.4 \mu m o l l^{-1}$, respectively (mean $\pm \mathrm{SD}, \mathrm{n}=199$ ) (J. I. González-Gordillo, Univ. Cádiz, pers. comm.). The highest $\mathrm{NH}_{4}{ }^{+}$concentrations during this period (around $25 \mathrm{mmol} \mathrm{l}^{-1}$ ) were observed during the incoming tidal surge. Annual mean water col-

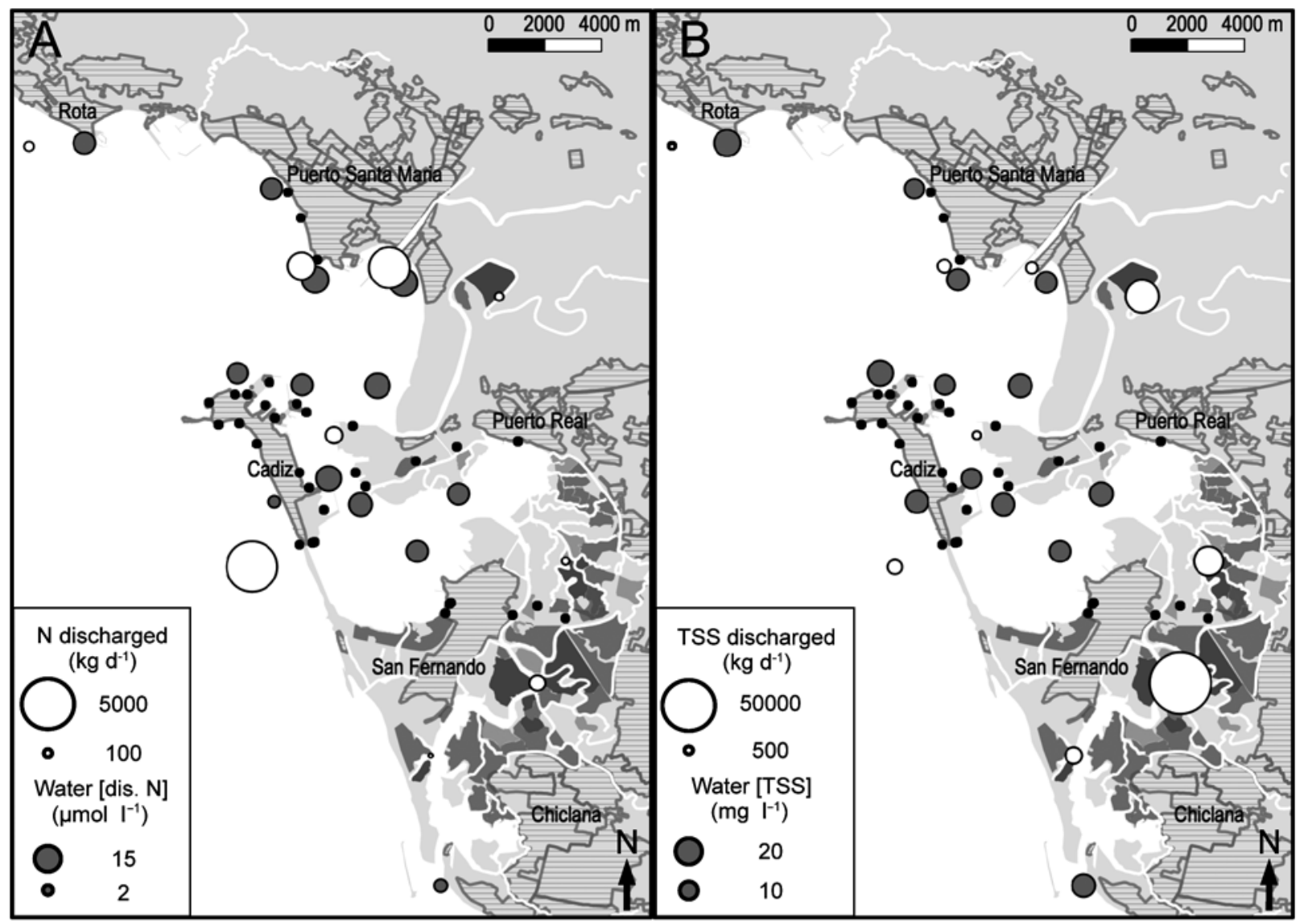

Fig. 2. (A) Total nitrogen discharges $\left(\mathrm{kg} \mathrm{d}^{-1}\right)$ from large urban and aquaculture point sources, and annual mean water column dissolved inorganic $\mathrm{N}$ concentration $\left(\mu \mathrm{mol} \mathrm{l^{-1 }}\right.$ ). (B) Total suspended solids discharges $\left(\mathrm{TSS}_{;} \mathrm{kg} \mathrm{d}^{-1}\right.$ ), and annual mean water column TSS concentration $\left(\mathrm{mg} \mathrm{l}^{-1}\right.$ ). Data provided by the 'Consejería de Medio Ambiente, Junta de Andalucia' 
umn TSS concentrations published by the Andalusian department for the environment in 2006 showed little spatial variation (Fig. 2B), ranging from a maximum of $18 \mathrm{mg} \mathrm{l}^{-1}$ to a minimum of $9.5 \mathrm{mg} \mathrm{l}^{-1}$.

Particulate organic matter sampling of point source discharges. Samples of TSS from the outfalls of a wastewater plant serving Puerto Real $(\mathrm{n}=2)$, intensive $(\mathrm{n}=3)$ and extensive $(\mathrm{n}=6)$ aquaculture operations (Fig. 1) were collected by filtering between 0.5 and 11 of water over a pre-ashed GF/F filter in June 2008. Filters were dried $\left(60^{\circ} \mathrm{C}, 4 \mathrm{~h}\right)$ and sent for isotope analysis.

Macrophyte tissue sampling. A total of 35 samples of Caulerpa prolifera were collected on 11 July 2006 using a random-stratified design in order to cover as large a region of the subtidal (covered with macrophytes) within the inner bay as possible. A further 17 samples of Cymodocea nodosa were also collected in the south-western corner of the bay as part of a longterm volunteer monitoring programme (FAMAR, http://famar.wordpress.com/) during June and July 2006. The position of each sampling point was recorded using a geographic positioning system (GPS, horizontal error $\pm 5 \mathrm{~m}$ ). Spatial coverage was not fully complete as some areas, such as the NE region were inaccessible by boat, whilst in others, such as the shipping channel, C. prolifera was not present. Deep subtidal samples were collected using an Eckman grab $\left(0.2 \times 0.14 \mathrm{~m}\right.$, surface area sampled: $\left.0.028 \mathrm{~m}^{2}\right)$ deployed from a small boat, whereas shallow subtidal and intertidal macrophyte samples were collected by hand using a quadrat $\left(0.04 \mathrm{~m}^{2}\right)$. Samples were stored in a cool box until they were transported to the laboratory (within $4 \mathrm{~h}$ ). No obvious epiphytes could be observed on the fronds of $C$. prolifera; however, epiphytes were observed on the leaves of seagrasses. Large material was removed from the leaves by hand (carefully scraping); however, no further epiphyte removal measures were taken. Macrophyte tissues were separated from the sediment, cleaned and dried at $60^{\circ} \mathrm{C}$ till they were at a constant weight (24 to $36 \mathrm{~h}$ ). All C. prolifera biomass (stolons and assimilators) and above-ground biomass (leaves and sheaths) of $C$. nodosa collected from each respective sampling point were grouped, weighed (allowing calculation of areal biomass, g DM $\mathrm{m}^{-2}$ ) and ground together to form a fine powder.

$\mathrm{C}: \mathbf{N}$ composition and isotopic analysis. Dried samples of macrophyte biomass (a single sub-sample from each site) and TSS from point sources were analysed in an elemental analyser coupled with an isotope ratio mass spectrometer (Europa Hydra IRMS coupled to a Carlo Erba NC250) for determination of nitrogen and carbon content (percentage $\mathrm{N}$ and $\mathrm{C}$ ) and atomic percent. Stable isotope ratios were converted to \%o notation using Peedee Belamite (PDB) and air- $\mathrm{N}_{2}$ as standards for $\mathrm{C}$ and $\mathrm{N}$, respectively.
Modelling hydrodynamic and light conditions. Digital elevation model: The depth of the inner bay was mapped at a fine scale using a $50 \mathrm{kHz}$ acoustic sounder (QTC-V) in June 2006. Details about the acoustic measurements can be found in Freitas et al. (2008). Depth measurements (lowest astronomical tide, LAT) were corrected for tidal differences (using tidal heights measured nearby in Cádiz port) and via kriging, used to produce a digital elevation model (DEM), from which the depth $(\mathrm{m})$ at each sampling point was derived.

Hydrodynamic model: A 2-dimensional, non-linear, finite-difference, hydrodynamic model developed by Alvarez et al. (1997) was applied to simulate the spatial distributions of tidal current parameters for the principal M2 constituent within the Bay of Cádiz. Using this model, current velocities $\left(u, \mathrm{~m} \mathrm{~s}^{-1}\right) 0.5 \mathrm{~m}$ above the benthic interface at each of the sampling locations were predicted in $1 \mathrm{~h}$ time intervals for a period of $3 \mathrm{mo}$ (11 April to 11 July 2006), allowing the calculation of median $u$ at each sampling point.

Benthic light dose model: Estimates of the downwelling photosynthetically active irradiance $\left(E_{\mathrm{s}}[\mathrm{PAR}]\right.$, $\mu \mathrm{mol}$ quanta $\mathrm{m}^{-2} \mathrm{~s}^{-1}$ ) at the surface of the water within the inner bay during the 3 mo prior to sampling (11 April to 11 July 2006, hourly resolution) were provided by a PAR sensor (ONSET computers) situated on the roof of Faculty of Environmental and Marine Sciences (near Puerto Real; Fig. 1). The water column depth ( $z, \mathrm{~m}, \mathrm{LAT})$ within the inner bay (at an hourly resolution) was estimated by combining the DEM and tidal depth coefficients from Cádiz port. Using this information and an estimation of the downwelling attenuation of $E_{\mathrm{s}}$ (PAR) within the water column $\left(k_{\mathrm{d}}[\mathrm{PAR}], \mathrm{m}^{-1}\right)$, irradiance at the surface of the benthos ( $\left.E_{\mathrm{b}}[\mathrm{PAR}]\right)$ was calculated according to the Beer-Lambert formulation (Beer 1865) (note for clarity the PAR notation has been left out):

$$
\mathrm{E}_{\mathrm{b}}=\mathrm{E}_{\mathrm{s}} \mathrm{e}^{-\mathrm{k}_{\mathrm{d}}^{\mathrm{z}}}
$$

Based on previous internal reports (I. Hernández, pers. comm.), $k_{\mathrm{d}}$ can be highly variable within the Bay of Cádiz (ranging from 0.2 to $4 \mathrm{~m}^{-1}$ ); depending on tidal stage, wind conditions and rainfall. Unfortunately, detailed information about water column attenuation during the period before sampling was not available; thus, we chose a single $k_{\mathrm{d}}$ value of $1 \mathrm{~m}^{-1}$ for the whole time period. Modelled $E_{\mathrm{b}}$ (PAR) was summed for the time period, and the mean daily light dose (mol quanta $\mathrm{m}^{-2} \mathrm{~d}^{-1}$ ) at each sampling point was calculated.

Data management and statistics. All available data were placed into a geographic information system (Quantum GIS 1.0.0, http://qgis.org) that was subsequently used to produce maps of the spatial distribution of variables (UTM 30N, ED50 datum). Two-sided $t$-tests were used to examine whether the mean tissue compositions of Caulerpa prolifera $(\mathrm{n}=35)$ and 
Cymodocea nodosa $(\mathrm{n}=17)$ were significantly different. Unless otherwise stated mean values are presented with $95 \%$ confidence intervals. Associations between C. prolifera tissue composition variables were examined using Pearson's correlation coefficient. Unless otherwise stated, $\mathrm{n}=35$. Statistical tests were considered significant at $\mathrm{p}<0.05$. Principle component analysis (PCA) was used to examine correlations between environmental variables and tissue composition of $C$. prolifera. Only axes with eigenvalues $>1$ were further considered. Statistics were carried out using R ( $\mathrm{R}$ version 2.8.1, The R Foundation for Statistical Computing, www.R-project.org).

\section{RESULTS}

\section{Stable isotopes and tissue composition}

Nitrogen stable isotope values $\left(\%{ }^{15} \mathrm{~N}\right)$ of TSS collected from urban and aquaculture discharges were $7 \pm 1.97$ (mean $\pm \mathrm{SD}, \mathrm{n}=2$ ) and $9 \pm 0.88($ mean $\pm \mathrm{CI}, \mathrm{n}=9$ ), respectively (Fig. 3). Carbon stable isotope values $\left(\%{ }^{13} \mathrm{C}\right.$ ) appeared to be distinct between the 2 sources, with values of $-26.5 \pm 0.14$ and $-16.5 \pm 0.61$ observed for urban and aquaculture effluents, respectively. $\mathrm{N}$ content of filters was $0.175 \pm 0.035$ and $0.06 \pm 0.02 \%$, whilst C content was higher, with $0.84 \pm 0.11$ and $0.57 \pm 0.14 \%$, for urban and aquaculture effluents, respectively.

$\delta^{15} \mathrm{~N}$ values of Caulerpa prolifera ranged from 8.1 to 4.4 , with the highest values appearing to be similar to both aquaculture and urban effluent (Fig. 3). $\delta^{13} \mathrm{C}$ values ranged from -10.2 to -16.8 ; these values were substantially more positive than urban effluent. $\delta^{15} \mathrm{~N}$ values of Cymodocea nodosa ranged from 3.4 to 5.9 and were significantly different from those of $C$. prolifera (2-sided $t$-test $, t=-11.18, \mathrm{df}=48.87, \mathrm{p}<0.001)$ as were

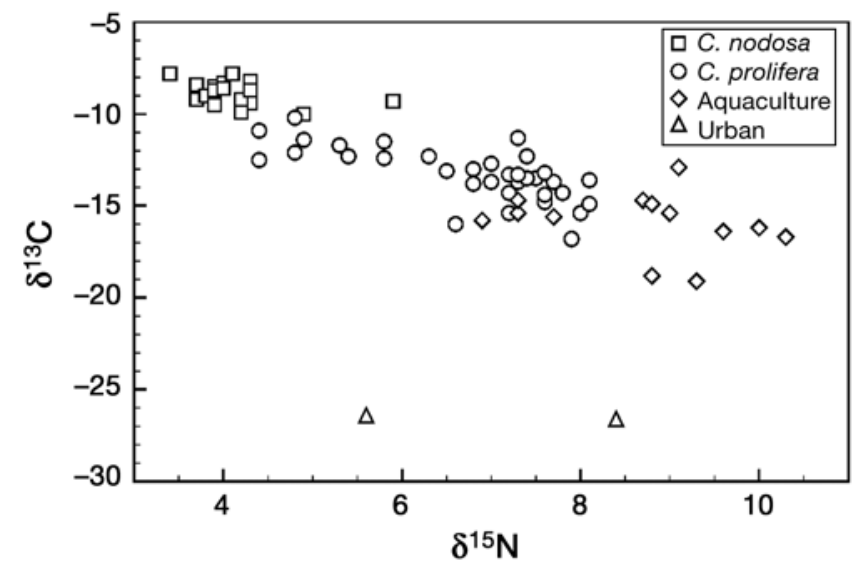

Fig. 3. Scatterplot of $\delta^{15} \mathrm{~N}$ versus $\delta^{13} \mathrm{C}$ for benthic macrophytes (Cymodocea nodosa and Caulerpa prolifera) and for total suspended solids collected from the discharge of an urban wastewater treatment plant and aquaculture facilities $\delta^{13} \mathrm{C}$ values (range: -8.2 to -9.9 ) (2-sided $t$-test, $t=$ 15.06, $\mathrm{df}=49.87, \mathrm{p}<0.001)$.

When isotope values were examined in a spatial context, a general gradient in Caulerpa prolifera isotopic values was observed (Fig. 4A, B). Samples collected from close to the navigation channel that connects the salt marshes with the outer bay had the highest $\delta^{15} \mathrm{~N}$ values, whereas samples collected in the southwestern corner, near the Cymodocea nodosa site, tended to have the lowest values. Approximately the inverse pattern was observed for $\delta^{13} \mathrm{C}$.

An indication that higher $\delta^{15} \mathrm{~N}$ and lower $\delta^{13} \mathrm{C}$ values represented an increased assimilation of nutrients from anthropogenic sources could be seen when $\delta^{15} \mathrm{~N}$ and $\delta^{13} \mathrm{C}$ were plotted against the percentage of $\mathrm{N}$ content (Fig. 5A, B). Caulerpa prolifera $\mathrm{N}$ content ranged from 3.0 to $4.9 \%$, whilst Cymodocea nodosa $\mathrm{N}$ content was lower (2-sided $t$-test, $t=-11.75, \mathrm{df}=33.65, \mathrm{p}<$ 0.001 ), ranging between 1.8 and $3 \%$. If the 2 species are considered together, a positive trend $(\mathrm{r}=0.82, \mathrm{p}<$ $0.001)$ of increasing $\delta^{15} \mathrm{~N}$ values was observed with increasing percentage of $\mathrm{N}$ (Fig. 5A). A similar, but inverse trend $(r=-0.89, p<0.001)$ was observed for $\delta^{13} \mathrm{C}$ (Fig. 5B).

As suggested by the strong correlation with isotope ratios, the $\mathrm{N}$ content of macrophytes showed a similar spatial pattern to $\delta^{15} \mathrm{~N}$ (Fig. 6A): the highest values were near the navigation channel and the minimum values were near the southwestern shore. In contrast the carbon content of Caulerpa prolifera tissues (range: 34 to $45 \%$ ) did not seem to have an obvious spatial distribution (Fig. 6B) and was only weakly correlated with isotope values $\left(\delta^{13} \mathrm{C}: \mathrm{r}=0.38 ; \delta^{15} \mathrm{~N}: \mathrm{r}=-0.36\right)$. Hence, mainly because of variation in the percentage of $\mathrm{N}$, the C:N ratios of $C$. prolifera showed a strong spatial gradient, with values ranging from 14.9 near the southern shore to 8.7 near the channel (Fig. 6C). Cymodocea nodosa C content (26.2 to $34.9 \%$ ) (2-sided $t$-test, $t=$ $-15.17, \mathrm{df}=37.56, \mathrm{p}<0.001)$ and $\mathrm{C}: \mathrm{N}$ ratios $(10.7$ to 18.7) (2-sided $t$-test, $t=4.55, \mathrm{df}=20.06, \mathrm{p}<0.001)$ were both significantly different to those of $C$. prolifera.

Caulerpa prolifera biomass ranged from 3.6 to $213.2 \mathrm{~g}$ $\mathrm{DM} \mathrm{m}^{-2}$ and appeared to have no obvious spatial pattern (Fig. 6D). Cymodocea nodosa above-ground biomass ranged from 85 to $370 \mathrm{~g} \mathrm{DM} \mathrm{m}^{-2}$ and was significantly higher than that of $C$. prolifera (2-sided $t$-test, $t=$ $4.74, \mathrm{df}=22.96, \mathrm{p}<0.001$ ).

\section{Associations with the environment}

Median water velocity at each of the Caulerpa prolifera sampling points ranged from 0.03 to $0.19 \mathrm{~m} \mathrm{~s}^{-1}$, with the highest velocities observed near the navigation channel (particularly near Puntales) and minimum 


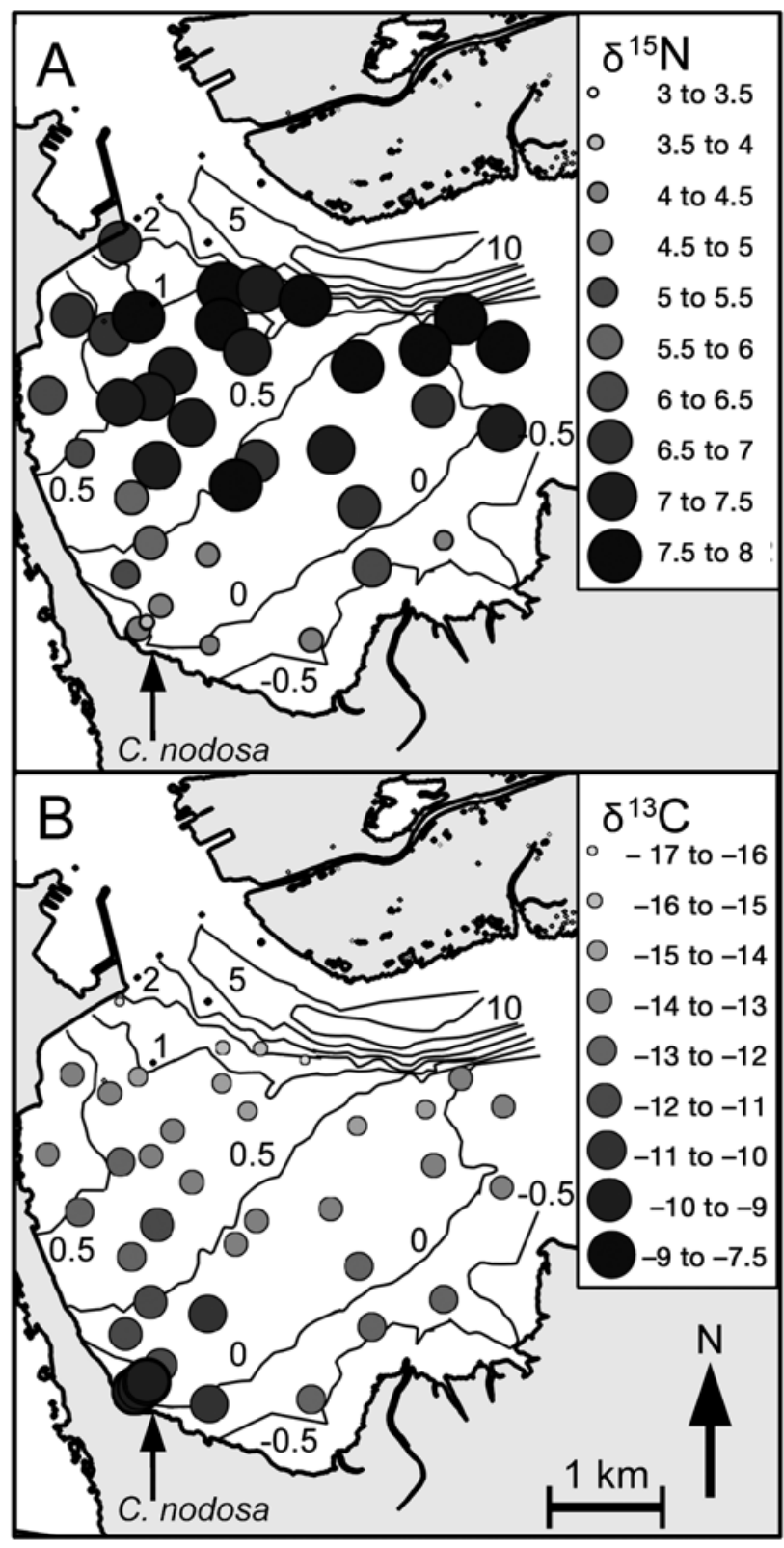

Fig. 4. Cymodocea nodosa, Caulerpa prolifera. Map of macrophyte (A) $\delta^{15} \mathrm{~N}$ and (B) $\delta^{13} \mathrm{C}$ values within the inner Bay of Cádiz, SW Spain. Contour lines represent depth (m, LAT). C. nodosa were only collected in the SW corner (marked by arrow)

values found near the southern shore. Thus, distance from the channel was a strong predictor of current velocity $(\mathrm{r}=-0.82, \mathrm{p}<0.001)$. Mean daily light dose (essentially a function of depth in our calculations) ranged from 1.2 to 10.7 mol quanta $\mathrm{m}^{-2} \mathrm{~d}^{-1}$. Minimum values were observed in the deepest regions $(>1 \mathrm{~m}$ depth) near the channel, while the highest values were observed in intertidal areas ( $<0 \mathrm{~m}$ depth), where sampling points were emersed for substantial periods dur-
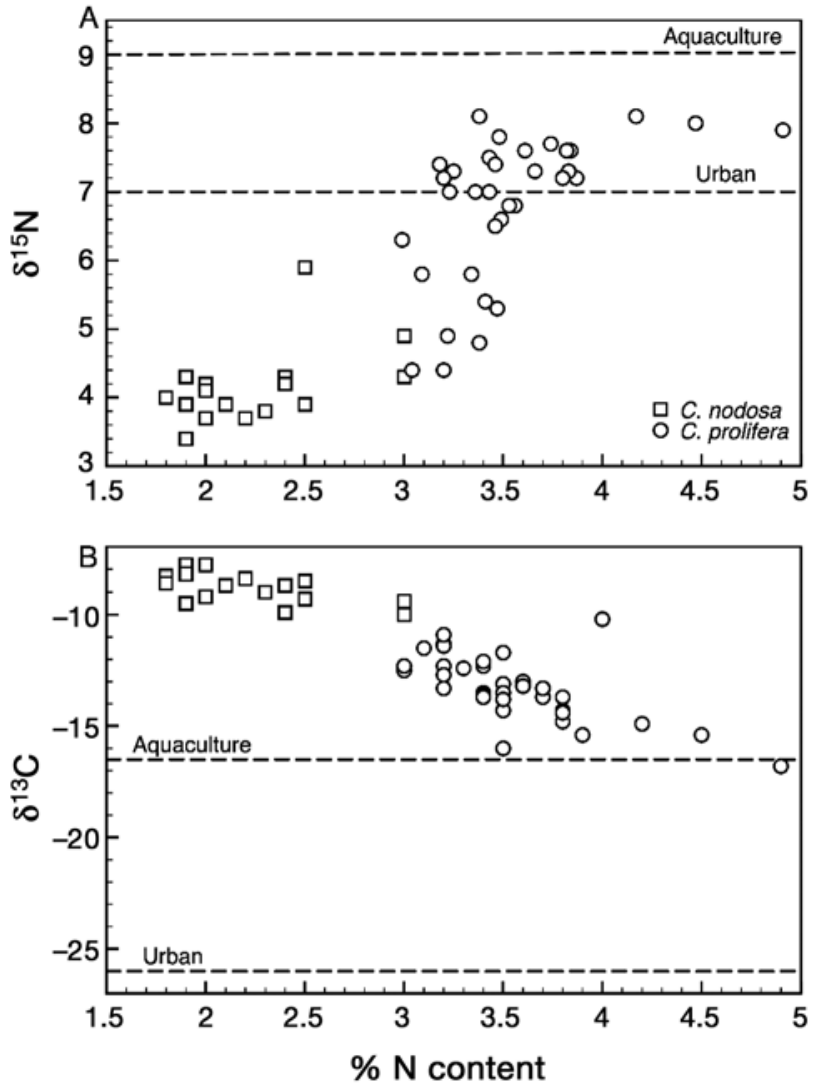

Fig. 5. Cymodocea nodosa, Caulerpa prolifera. (A) $\delta^{15} \mathrm{~N}$ and (B) $\delta^{13} \mathrm{C}$ values of C. nodosa and C. prolifera tissues plotted versus percentage of $\mathrm{N}$ content. Mean isotopic values of total suspended solids collected from the discharge of an urban wastewater treatment plant and various aquaculture facilities are presented as dashed lines

ing spring-neap cycles. Because of the morphology of the inner bay, shallow depths were situated near the channel in the east of the bay, meaning that, compared to $u$, distance from the channel was not as strong a predictor of light dose $(\mathrm{r}=-0.45, \mathrm{p}<0.01)$.

PCA (Fig. 7) revealed that the variation in Caulerpa prolifera tissue composition, biomass and the corresponding environmental conditions at each sampling point were explained by 2 component axes (eigenvalues > 1); Axes 1 and 2 accounted for 56 and $15 \%$ of the variation, respectively. C. prolifera tissue $\delta^{13} C_{,} \delta^{15} \mathrm{~N}$, $\mathrm{C}: \mathrm{N}$ ratios and percentage of $\mathrm{N}$ values were all associated with each other, and with Axis 1, which appeared to represent increasing median $u$ associated with decreasing distance from the navigation channel (Table 1). Axis 2 appeared to represent variation in biomass (DM), which, as noted previously, did not have a clear spatial distribution (Fig. 6D). C content and mean light dose were associated with each other, and with both Axes 1 and 2. 


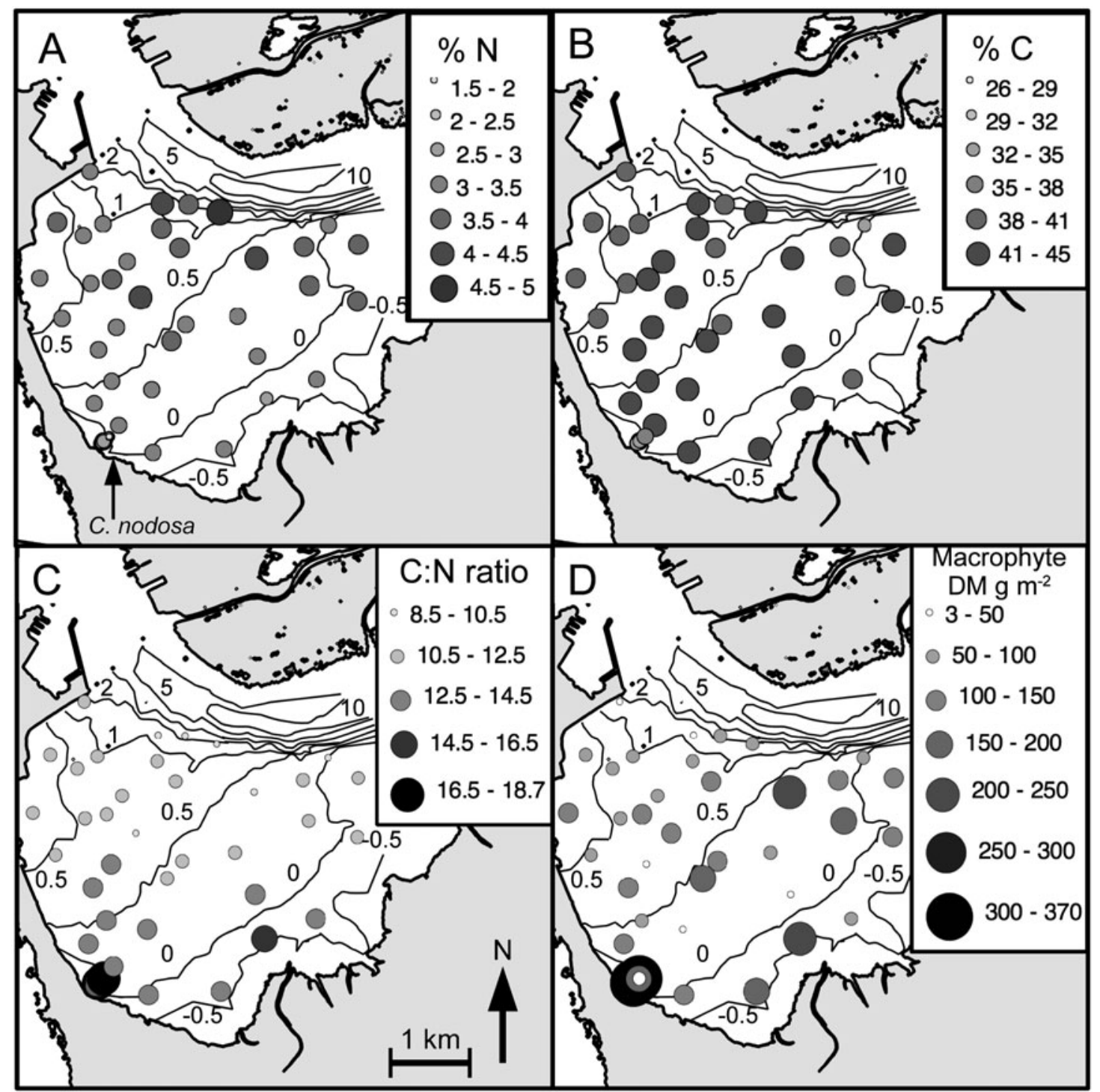

Fig. 6. Cymodocea nodosa, Caulerpa prolifera. Map of macrophyte (A) nitrogen content, (B) carbon content, (C) C:N ratio and (D) areal biomass within the inner Bay of Cádiz, SW Spain. Contour lines represent depth (m, LAT)

\section{DISCUSSION}

$\delta^{15} \mathrm{~N}$ values of Caulerpa prolifera from the inner Bay of Cádiz were high when compared to reports of macrophytes from 'pristine' areas? $\delta^{15} \mathrm{~N}$ values of between 1 and 5 (Hemminga \& Mateo 1996, Jones et al. 2001, Vizzini \& Mazzola 2006). Values as high as 8.1 were found near the navigation channel (Figs. $3 \& 4$ ), and only in a relatively small band situated adjacent to the southern shore were $\delta^{15} \mathrm{~N}$ values of $<6$ observed, suggesting the influence of aquaculture and urban effluents ( $\delta^{15} \mathrm{~N}$ values between 5.6 and 15.6) throughout most of the inner bay.

The strong positive association between isotope values and the $\mathrm{N}$ content of macrophyte tissues (Fig. 5A) indi- cates that the increasing influence of anthropogenic nutrient sources also represented increasing benthic $\mathrm{N}$ assimilation. $\mathrm{N}$ contents of Caulerpa prolifera were lower near the southern shore when compared to near the channel (Fig. 6A), suggesting that, relative to the demands of growth, the supply of $\mathrm{N}$ was lower (Baird \& Middleton 2004). Although, as the minimum N content (3.0\% DM) was higher than the subsistence $\mathrm{N}$ quota of C. prolifera (1.7\%; Malta et al. 2005), it is unlikely that $\mathrm{N}$ supply limited growth. Cymodocea nodosa $\mathrm{N}$ content was rather similar to $C$. prolifera samples from the same region and showed a similar tendency, i.e. an association between isotope values and $\mathrm{N}$ content, suggesting that the 2 species may potentially be used in combination to map anthropogenic nutrient inputs. 


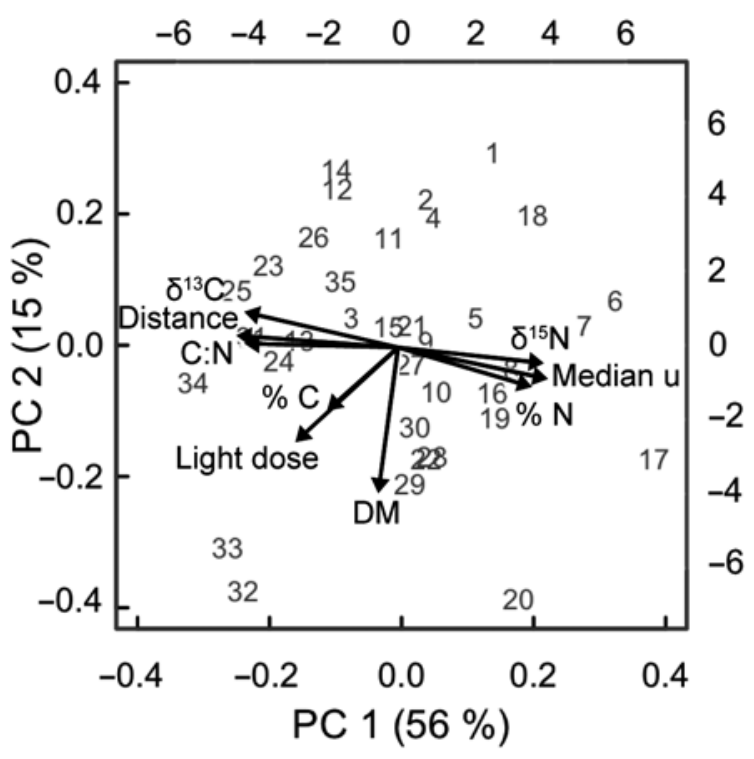

Fig. 7. Caulerpa prolifera. Biplot of tissue composition and corresponding environmental variables at each sampling point plotted against principal component (PC) Axes 1 and 2

Table 1. Variable correlations with principle component (PC) axes. DM: dry mass

\begin{tabular}{|lcc|}
\hline Variable & PC1 & PC2 \\
\hline$\delta^{13} \mathrm{C}$ & -0.40 & 0.15 \\
$\delta^{15} \mathrm{~N}$ & 0.37 & -0.09 \\
$\% \mathrm{C}$ & -0.19 & -0.34 \\
$\% \mathrm{~N}$ & 0.33 & -0.21 \\
$\mathrm{C}: \mathrm{N}$ ratio & -0.40 & -0.01 \\
Biomass (DM) & -0.05 & -0.73 \\
Distance & -0.42 & 0.04 \\
Median $u$ & 0.38 & -0.17 \\
Light dose & -0.27 & -0.49 \\
\hline
\end{tabular}

Distance from the channel, where most nutrients from aquaculture and urban effluents are transported through the system (Fig. 1), appeared to be the major factor associated with the supply of $\mathrm{N}$ to benthic communities within the inner Bay of Cádiz (Fig. 7, Table 1). In which form this $\mathrm{N}$ is transported, e.g. particulate, dissolved organic, or inorganic, is at present unclear. The strong correlation between median current velocities and distance from the channel ( $\mathrm{r}=-0.82)$, suggests that the benthic $\mathrm{N}$ supply may also be directly linked to current velocity. Which, via its effect on mass transport, can have a strong, non-linear influence on foliar N uptake (Hurd et al. 1996, Thomas et al. 2000, Morris et al. 2008) and particle trapping (Peralta et al. 2008), resulting in differences in the $\mathrm{N}$ content of macrophyte communities (Cornelisen et al. 2007).

$\delta^{13} \mathrm{C}$ values appeared to be mainly influenced by the contribution of $C$ from anthropogenic sources (Fig. 4B), i.e. the distance from nutrient sources. Although the weak positive correlation between light dose and $\delta^{13} \mathrm{C}$ values $(\mathrm{r}=0.43, t=2.73, \mathrm{df}=33, \mathrm{p}<0.05)$ does hint at the involvement of $\mathrm{C}$ isotopic fractionation effects that are related to a gradient in light availability (Grice et al. 1996). Future examination of spatial variations in water column $\mathrm{C}$ availability and isotopic composition in combination with $K_{\mathrm{d}}$ (PAR), which is also likely to be influenced by both distance from the channel and hydrodynamics, may help to assess the extent of photosynthetic isotopic fractionation. Differences in isotope and tissue contents were clearly observable between Caulerpa prolifera and Cymodocea nodosa, indicating the different photosynthetic and growth properties of each species. The high $\delta^{13} \mathrm{C}$ values (>-10) of C. nodosa tissues and some samples of $C$. prolifera $(-10.2)$ found in the shallowest regions suggest reliance on dissolved bicarbonate, rather than $\mathrm{CO}_{2}$ as a $\mathrm{C}$ source (Raven et al. 2002), although emersion of plants may also play a role (Cooper \& McRoy 1988). Carbon-concentrating mechanisms have been documented in C. nodosa (Beer \& Waisel 1979, Invers et al. 1999) and in many macroalgal species (although their occurrence in Caulerpa spp. is still unconfirmed) (Raven et al. 2002). Local depletion of dissolved $\mathrm{CO}_{2}$ caused by the high uptake rates of primary producers (Perez Llorens et al. 2004, Obrador et al. 2007), combined with high temperatures and low water refreshment rates, are likely to favour increased reliance on dissolved bicarbonate in the shallow, southern region of the bay.

The low C:N ratio of Caulerpa prolifera (Atkinson \& Smith 1983, Duarte 1992) suggests that this species thrives in conditions with a high nutrient supply (Malta et al. 2005), which, combined with its tolerance of a wide range of light levels (Gacia et al. 1996) (1.2 to 10.7 mol quanta $\mathrm{m}^{-2} \mathrm{~d}^{-1}$ ), is likely to be an important factor ensuring its widespread distribution within the inner bay. The high $\mathrm{C}$ and $\mathrm{N}$ content of this species suggests a strong potential to store nutrients; with a mean biomass of $97 \pm 18 \mathrm{~g} \mathrm{DM} \mathrm{m}^{-2}$ covering an area of $\sim 13 \mathrm{~km}^{2}$, $524 \mathrm{t} \mathrm{C}$ and $45 \mathrm{t} \mathrm{N}$ are trapped within C. prolifera during summer. On the other hand, because of the higher areal biomass of Cymodocea nodosa (196 $\pm 40 \mathrm{~g} \mathrm{DM}$ $\mathrm{m}^{-2}$ ), areal $\mathrm{C}$ and $\mathrm{N}$ would be 58 and $26 \%$ higher for the equivalent area of seagrass habitat.

In summary, although the Bay of Cádiz is highly urbanised and has a number of urban wastewater and aquaculture nutrient discharges situated within the area, annual mean water column nutrient and TSS concentrations are within recommended limits for the natural park (Consejería de Medio Ambiente, Junta de Andalucia; Fig. 2), suggesting low to moderate nutrient contamination and 'no threat to the marine ecosystem' (Carrasco et al. 2003). Nevertheless, examination of the nutrient contents and stable iso- 
tope ratios of Caulerpa prolifera revealed the influence of anthropogenic nutrient sources throughout most of the inner bay. $\delta^{15} \mathrm{~N}$ values of suspended solids collected from aquaculture and urban effluent were similar to those in the macroalgae and had a strong association with $\mathrm{N}$ content. Anthropogenic nutrient supply strongly influenced the stoichiometry of the plants and was highly associated with median current velocities and distance from the source. Thus, mass transfer of nutrients to the benthos appeared to be highly influenced by the environmental gradients within the bay. Cymodocea nodosa inhabiting the shallow, low-water velocity, south-western shore had significantly lower $\mathrm{N}$ content and $\delta^{15} \mathrm{~N}$ values than the C. prolifera population, suggesting that lower $\mathrm{N}$ availability may have a role in promoting the stable coexistence of seagrasses. The broad distribution of C. prolifera and its wide tolerance to environmental conditions (particularly high $\mathrm{N}$ and low light) means it is likely to play a large role in the cycling of nutrients within the inner Bay of Cádiz. Being also sessile and easy to handle, C. prolifera is a useful indicator species that via the analysis of its tissue composition can provide information about the extent and impacts of anthropogenic nutrient inputs. With sufficient 'background information' and a clear tracer signal from the source, examination of macrophyte stable isotope ratios can provide a highly effective tool to aid in the management of nutrient inputs within shallow, coastal zones (McClelland et al. 1997, Costanzo et al. 2001, 2005).

Acknowledgements. This work and E.P.M were supported by a European Union Marie Curie host fellowship for transfer of knowledge, MTKD-CT-2004-509254, the Spanish national project EVAMARIA (CTM2005-00395/MAR) and the regional government of Andalusia project FUNDIV (P07-RNM-2516). This work was also supported by the Portuguese FCT (Fundação para a Ciência e a Tecnologia) under the project ACO SHELF (POCI/MAR/56441/2004-PPCDT/MAR/56441/2004). We extend our deepest gratitude to C. Megina and the team of volunteers that helped with sample collection and processing. Thanks to J. I. Gonzalez-Gordillo (Project CTM 2005-00024) for kindly providing data about water nutrient concentrations, C. M. Garcia and F. Echevarría (Project P06RNM-01637) for supplying isotope data from point sources, and the 'Consejería de Medio Ambiente' and 'Consejería de Agricultura y Pesca' from the 'Junta de Andalucia' for making available vital background information.

\section{LITERATURE CITED}

Alvarez O, Tejedor B, Tejedor L (1997) Simulación hidrodinámica en el área de la Bahía de Cádiz. Análisis de las constituyentes principales. IV Jornadas Españolas de Ingeniería de Puertos y Costas, Servicio de Publicaciones de la Universidad Politecnica de Valencia 98:125-136

Atkinson MJ, Smith SV (1983) C:N:P ratios of benthic marine plants. Limnol Oceanogr 28:568-574
Bachelet G, de Montaudouin X, Auby I, Labourg PJ (2000) Seasonal changes in macrophyte and macrozoobenthos assemblages in three coastal lagoons under varying degrees of eutrophication. ICES J Mar Sci 57:1495-1506

Baird ME, Middleton JH (2004) On relating physical limits to the carbon:nitrogen ratio of unicellular algae and benthic plants. J Mar Syst 49:169-175

Beer A (1865) Einleitung in die Elektrostatik, die Lehre vom Magnetismus und die Elektrodynamik, Vol F. Vieweg und Sohn, Wiesbaden

> Beer S, Waisel Y (1979) Some photosynthetic carbon fixation properties of seagrasses. Aquat Bot 7:129-138

Benedict CR, Wong WWL, Wong JHH (1980) Fractionation of stable carbon isotopes in seagrasses. Plant Physiol 65: 512-517

> Brabandere LDE, Frazer TK, Montoya JP (2007) Stable nitrogen isotope ratios of macrophytes and associated periphyton along a nitrate gradient in two subtropical, spring-fed streams. Freshw Biol 52:1564-1575

> Brun FG, Hernandez I, Vergara JJ, Peralta G, Perez-Llorens JL (2002) Assessing the toxicity of ammonium pulses to the survival and growth of Zostera noltii. Mar Ecol Prog Ser 225:177-187

Carrasco M, Lopez-Ramirez JA, Benavente J, Lopez-Aguayo F, Sales D (2003) Assessment of urban and industrial contamination levels in the Bay of Cádiz, SW Spain. Mar Pollut Bull 46:335-345

Chisholm JRM, Moulin P (2003) Stimulation of nitrogen fixation in refractory organic sediments by Caulerpa taxifolia (Chlorophyta). Limnol Oceanogr 48:787-794

Cohen RA, Fong P (2004) Nitrogen uptake and assimilation in Enteromorpha intestinalis (L.) link (Chlorophyta): using ${ }^{15} \mathrm{~N}$ to determine preference during simultaneous pulses of nitrate and ammonium. J Exp Mar Biol Ecol 309:67-77

Collado-Vides L (2002) Morphological plasticity of Caulerpa prolifera (Caulerpales, Chlorophyta) in relation to growth form in a coral reef lagoon. Bot Mar 45:123-129

Cooper L, McRoy C (1988) Stable carbon isotope ratio variations in marine macrophytes along intertidal gradients. Oecologia 77:238-241

Cornelisen CD, Thomas FIM (2006) Water flow enhances ammonium and nitrate uptake in a seagrass community. Mar Ecol Prog Ser 312:1-13

Cornelisen C, Wing S, Clark K, Bowman M, Frew R, Hurd C (2007) Patterns in the $\delta^{13} \mathrm{C}$ and $\delta^{15} \mathrm{~N}$ signature of Ulva pertusa: interaction between physical gradients and nutrient source pools. Limnol Oceanogr 52:820-832

> Corzo A, Van Bergeijk S, García-Robledo E (2009) Effects of green macroalgal blooms on intertidal sediments: net metabolism and carbon and nitrogen contents. Mar Ecol Prog Ser 380:81-93

> Costanzo S, O'Donohue MJ, Dennison W (2000) Gracilaria edulis (Rhodophyta) as a biological indicator of pulsed nutrients in oligotrophic waters. J Phycol 36:680-685

> Costanzo SD, O'Donohue MJ, Dennison WC, Loneragan NR, Thomas M (2001) A new approach for detecting and mapping sewage impacts. Mar Pollut Bull 42:149-156

Costanzo SD, Udy J, Longstaff B, Jones A (2005) Using nitrogen stable isotope ratios (delta N-15) of macroalgae to determine the effectiveness of sewage upgrades: changes in the extent of sewage plumes over four years in Moreton Bay, Australia. Mar Pollut Bull 51:212-217

> de la Paz M, Gómez-Parra A, Forja J (2008) Variability of the partial pressure of $\mathrm{CO}_{2}$ on a daily-to-seasonal time scale in a shallow coastal system affected by intensive aquaculture activities (Bay of Cádiz, SW Iberian Peninsula). Mar Chem 110:195-204 
Drake P, Arias AM (1995) Distribution and production of Microdeutopus gryllotalpa (Amphipoda: Aoridae) in a shallow coastal lagoon in the Bay of Cádiz, Spain. J Crustac Biol 15:454-465

Duarte CM (1992) Nutrient concentration of aquatic plants: patterns across species. Limnol Oceanogr 37:882-889

Enríquez S, Pantoja-Reyes N (2005) Form-function analysis of the effect of canopy morphology on leaf self-shading in the seagrass Thalassia testudinum. Oecologia 145: $234-242$

Enriquez S, Rodriguez-Roman A (2006) Effect of water flow on the photosynthesis of three marine macrophytes from a fringing-reef lagoon. Mar Ecol Prog Ser 323:119-132

European Environment Agency (2006) Priority issues in the Mediterranean environment. Report No. 4, EEA, Copenhagen

Ferrón S, Ortega T, Forja JM (2009) Benthic fluxes in a tidal salt marsh creek affected by fish farm activities: Río San Pedro (Bay of Cádiz, SW Spain). Mar Chem 113:50-62

France R, Holmquist J, Chandler M, Cattaneo A (1998) $\delta^{15} \mathrm{~N}$ evidence for nitrogen fixation associated with macroalgae from a seagrass-mangrove coral reef system. Mar Ecol Prog Ser 167:297-299

Freitas R, Rodrigues AM, Morris EP, Perez-Llorens JL, Quintino V (2008) Single-beam acoustic ground discrimination of shallow water habitats: $50 \mathrm{kHz}$ or $200 \mathrm{kHz}$ frequency survey? Estuar Coast Shelf Sci 78:613-622

Fry B (2006) Stable isotope ecology. Springer, New York

> Gacia E, Littler MM, Littler DS (1996) The relationships between morphology and photosynthetic parameters within the polymorphic genus Caulerpa. J Exp Mar Biol Ecol 204:209-224

Grice AM, Loneragan NR, Dennison WC (1996) Light intensity and the interactions between physiology, morphology and stable isotope ratios in five species of seagrass. J Exp Mar Biol Ecol 195:91-110

- Hemminga MA, Mateo MA (1996) Stable carbon isotopes in seagrasses: variability in ratios and use in ecological studies. Mar Ecol Prog Ser 140:285-298

Herbert RA (1999) Nitrogen cycling in coastal marine ecosystems. FEMS Microbiol Rev 23:563-590

Herbert DA, Fourqurean JW (2008) Ecosystem structure and function still altered two decades after short-term fertilization of a seagrass meadow. Ecosystems 11:688-700

Hurd C, Harrison P, Druehl L (1996) Effect of seawater velocity on inorganic nitrogen uptake by morphologically distinct forms of Macrocystis integrifolia from wave-sheltered and exposed sites. Mar Biol 126:205-214

Iizumi H, Yamamuro M (2000) Nitrogen fixation activity by periphytic blue-green algae in a seagrass bed on the Great Barrier Reef. Jpn Agric Res Q 34:69-73

Inglett PW, Reddy KR (2006) Investigating the use of macrophyte stable $\mathrm{C}$ and $\mathrm{N}$ isotopic ratios as indicators of wetland eutrophication: patterns in the P-affected Everglades. Limnol Oceanogr 51:2380-2387

> Invers O, Perez M, Romero J (1999) Bicarbonate utilization in seagrass photosynthesis: role of carbonic anhydrase in Posidonia oceanica (L.) Delile and Cymodocea nodosa (Ucria) Ascherson. J Exp Mar Biol Ecol 235:125-133

Jickells TD (1998) Nutrient biogeochemistry of the coastal zone. Science 281:217-222

- Jones AB, O'Donohue MJ, Udy J, Dennison WC (2001) Assessing ecological impacts of shrimp and sewage effluent: biological indicators with standard water quality analyses. Estuar Coast Shelf Sci 52:91-109

> Koch EW (1994) Hydrodynamics, diffusion-boundary layers and photosynthesis of the seagrasses Thalassia tes- tudinum and Cymodocea nodosa. Mar Biol 118:767-776

López de la Rosa IL, Rodriguez A, Raso JEG (2006) Seasonal variation and structure of a decapod (Crustacea) assemblage living in a Caulerpa prolifera meadow in Cádiz Bay (SW Spain). Estuar Coast Shelf Sci 66:624-633

Le point G, Dauby P, Gobert S (2004) Applications of C and N stable isotopes to ecological and environmental studies in seagrass ecosystems. Mar Pollut Bull 49:887-891

Lund LJ, Horne AJ, Williams AE (1999) Estimating denitrification in a large constructed wetland using stable nitrogen isotope ratios. Ecol Eng 14:67-76

Macías JC, del Castillo F, Villarías RM, Gaiteiro JM (2005) Zonas de interés para cultivos marinos: identificación y gestión para el desarrollo ordenado de la acuicultura en Andalucía. Bol Inst Esp Oceanogr 21:47-55

> Malta EJ, Ferreira DG, Vergara JJ, Perez-Llorens JL (2005) Nitrogen load and irradiance affect morphology, photosynthesis and growth of Caulerpa prolifera (Bryopsidales: Chlorophyta). Mar Ecol Prog Ser 298:101-114

Manzano Harriero JC, Márquez JMN, Perea MA, SánchezLamadrid A and others (2002) Bahía de Cádiz: Protección de los recursos naturales pesqueros y aplicaciones para instalaciones acuícolas. Dirección General de Pesca y Acuicultura, Consejería de Agricultura y Pesca, Junta de Andalucía, Sevilla

McClelland JW, Valiela I, Michener RH (1997) Nitrogen-stable isotope signatures in estuarine food webs: a record of increasing urbanization in coastal watersheds. Limnol Oceanogr 42:930-937

Morris EP, Peralta G, Brun F, van Duren L, Bouma TJ, PerezLlorens JL (2008) Interaction between hydrodynamics and seagrass canopy structure: spatially explicit affects on ammonium uptake rates. Limnol Oceanogr 53:1531-1539

Nishihara GN, Ackerman JD (2007) On the determination of mass transfer in a concentration boundary layer. Limnol Oceanogr Methods 5:88-96

Obrador B, Pretus JL, Menéndez M (2007) Spatial distribution and biomass of aquatic rooted macrophytes and their relevance in the metabolism of a Mediterranean coastal lagoon. Sci Mar 71:57-64

> Peralta G, van Duren LA, Morris EP, Bouma TJ (2008) Consequences of shoot density and stiffness for ecosystem engineering in flow dominated areas: a hydrodynamic flume study. Mar Ecol Prog Ser 368:103-115

$>$ Perez-Hurtado A, Goss-Custard JD, Garcia F (1997) The diet of wintering waders in Cádiz Bay, southwest Spain. Bird Study 44:45-52

> Perez-Llorens JL, Brun FG, Andria J, Vergara JJ (2004) Seasonal and tidal variability of environmental carbon related physico-chemical variables and inorganic $\mathrm{C}$ acquisition in Gracilariopsis longissima and Enteromorpha intestinalis from Los Toruños salt marsh (Càdiz Bay, Spain). J Exp Mar Biol Ecol 304:183-201

> Raven JA, Walker DI, Johnston AM, Handley LL, Kubler JE (1995) Implications of ${ }^{13} \mathrm{C}$ natural abundance measurements for photosynthetic performance by marine macrophytes in their natural environment. Mar Ecol Prog Ser 123:193-205

> Raven JA, Johnston AM, Kubler JE, Korb R and others (2002) Mechanistic interpretation of carbon isotope discrimination by marine macroalgae and seagrasses. Funct Plant Biol 29:355-378

Rueda JL, Salas C (2003) Seasonal variation of a molluscan assemblage living in a Caulerpa prolifera meadow within the inner Bay of Cádiz (SW Spain). Estuar Coast Shelf Sci 57:909-918

Sales D, Gomez A, Cantero D (1983) Incidence of urban 
sewage disposal in the salt-pond areas of the south of the Bay of Cádiz. Mar Pollut Bull 14:447-452

Scheffer M, Carpenter S, Foley JA, Folke C, Walker B (2001) Catastrophic shifts in ecosystems. Nature 413:591-596

Schlesinger WH (2009) On the fate of anthropogenic nitrogen. Proc Natl Acad Sci USA 106(1):203-208

Short FT, Burdick DM, Kaldy JE (1995) Mesocosm experiments quantify the effects of eutrophication on eelgrass, Zostera marina. Limnol Oceanogr 40:740-749

Small C, Nicholls RJ (2003) A global analysis of human settlement in coastal zones. J Coast Res 19:584-599

Smith VH, Joye SB, Howarth RW (2006) Eutrophication of freshwater and marine ecosystems. Limnol Oceanogr 51:351-355

Staal M, Thar R, Kühl M, van Loosdrecht MCM, Wolf G, de Brouwer JFC, Rijstenbil JW (2007) Different carbon isotope fractionation patterns during the development of phototrophic freshwater and marine biofilms. Biogeosciences 4:613-626

Sundback K, Miles A, Hulth S, Pihl L, Engstrom P, Selander E, Svenson A (2003) Importance of benthic nutrient regeneration during initiation of macroalgal blooms in shallow bays. Mar Ecol Prog Ser 246:115-126

Tchobanoglous G, Burton FL, Stensel HD (2003) Wastewater engineering: treatment and reuse, 4 th edn. McGraw-Hill Science/Engineering/Math, New York

Thomas FIM, Cornelisen CD, Zande JM (2000) Effects of water velocity and canopy morphology on ammonium uptake by seagrass communities. Ecology 81:2704-2713

Editorial responsibility: Rodney Forster,

Lowestoft, UK
Tovar A, Moreno C, Manuel-Vez MP, Garca-Vargas M (2000a) Environmental implications of intensive marine aquaculture in earthen ponds. Mar Pollut Bull 40: 981-988

- Tovar A, Moreno C, Manuel-Vez MP, Garca-Vargas M (2000b) Environmental impacts of intensive aquaculture in marine waters. Water Res 34:334-342

Van Der Voet E, Kleijn R, Udo De Haes HA (1996) Nitrogen pollution in the European Union-Origins and proposed solutions. Environ Conserv 23:120-132

- Vizzini S, Mazzola A (2004) Stable isotope evidence for the environmental impact of a land-based fish farm in the western Mediterranean. Mar Pollut Bull 49:61-70

Vizzini S, Mazzola A (2006) The effects of anthropogenic organic matter inputs on stable carbon and nitrogen isotopes in organisms from different trophic levels in a southern Mediterranean coastal area. Sci Tot Environ 368(2-3): 723-731

Welsh DT, Bartoli M, Nizzoli D, Castaldelli G, Riou SA, Viaroli P (2000) Denitrification, nitrogen fixation, community primary productivity and inorganic-N and oxygen fluxes in an intertidal Zostera noltii meadow. Mar Ecol Prog Ser 208:65-77

Williams SL (1984) Uptake of sediment ammonium and translocation in a marine green macroalga Caulerpa cupressoides. Limnol Oceanogr 29:374-379

> Worm B, Barbier EB, Beaumont N, Duffy JE and others (2006) Impacts of biodiversity loss on ocean ecosystem services. Science 314:787-790

Submitted: March 25, 2008; Accepted: June 30, 2009 Proofs received from author(s): September 2, 2009 